\title{
ANEMOPHILOUS PLANT POLLEN IN SPRING SPECIFIC HONEYS FROM THE RZESZÓW AREA
}

\author{
Katarzyna Ceglińska \\ University of Life Sciences in Lublin, \\ Department of Botany, Akademicka 15, 20-950 Lublin, Poland \\ e-mail:kasianik@o2.pl
}

Received: 28.09.2007

\section{S u m m a r y}

The present study comprises pollen analyses of 23 samples of spring specific honeys collected from apiaries situated in 12 communes in the Rzeszów area during the 2005 -2006 apicultural season. Forty two pollen taxa were identified in the examined material, of which 31 nectariferous and 11 non-nectariferous anemophilous plants. Among the nectariferous plants, the highest pollen frequency was found for Brassicaceae (others) (95.7\%), Rubus type (91.3\%) and Prunus type (86.9\%). The presence of anemophilous pollen grains was recorded in all the samples, with Poaceae reaching the highest frequency $(69.8 \%)$. The frequency of over $50 \%$ was characteristic of Quercus and Rumex, while the lowest frequency (less than 10\%) was recorded for Cerealia, Corylus avellana and Humulus lupulus. The highest participation was found for Quercus, whose pollen grains constituted as much as $80 \%$ of anemophilous pollen grains in a single sample. The lowest participation (below 3\%) was found for Rumex, Pinus and Artemisia. Among all the taxa of pollen grains found in a single sample, Poaceae pollen reached the highest share of anemophilous pollen in a sample of honey from fruit trees $(10 \%)$, whereas Quercus pollen in one honey from Brassica napus (7.8\%) and in one honey from Acer (4.5\%). The pollen share of the remaining anemophilous taxa in the examined honeys ranged between $0.2 \%$ and $2.9 \%$. The identified anemophilous taxa belong to 10 botanical families. In 19 out of 23 examined samples of honeys, small indicators of honeydew were discovered.

Key words: pollen analysis of honeys, anemophilous plants, Rzeszów

\section{INTRODUCTION}

The specific flower structure of some anemophilous plants makes pollination possible both by means of wind and insects. Pollen grains of these plants are produced in an enormous quantity and they are small, dry and light, sometimes with outgrowths aiding in wind dispersal. Pollen of anemophilous plants is of considerable importance for bees, mainly because it occurs abundantly in early spring, the time of intensive deve- lopment of bee colonies. Microscopic analysis often shows the presence of anemophilous plant pollen in bee products, which reflects honeybees' interest in such pollen. The presence of pollen of such plants in the honeys is mainly due to some accidental contamination.

Since the 1930's, pollen analysis of honeys was a reliable method of describing their specific variety, as well as their biological and geographical origin. In 1939 M a uri zi o elaborated a quantitative method of pollen analysis of honeys. In Poland, microscopic examination of honeys was initiated by Demianowiczowie (1955) and was continued by various scientists, among others by Warakomska (1985, 1997, 1999), Warakom ska and Jaroszyńska (1992); Wróblewska (2002).

\section{MATERIALS AND METHODS}

The object of this study consists of 23 samples of spring specific honeys obtained from the Rzeszów area in the years 2005-2006. The material was collected from apiaries situated in 12 communes (Tab. 1). Pollen analysis of honeys was conducted in accordance with the recommendations of the International Commission for Bee Botany (Louveaux et al. 1978) and the Polish standard for bee-honey, Polska Norma PN-88/A77626 Miód Pszczeli (1988). From each honey sample, a glycerogelatine preparation was made in two repetitions. In each of the preparations, at least 300 grains of pollen were counted in consecutive visual fields (Moar, 1985 ) in order to identify the bee plants and to confirm the specific variety of honeys declared by beekeepers. In case of doubt, while identifying the grains of pollen, comparative preparations and keys were used (Z a n d e r, 1935, 1937; S aw y e r, 1981, 1988; Ricciardelli d'Albore, 1998). The presence of honeydew indicators, i.e. fungi spores and fungi and algae hyphae, was also registered. The pollen ratios of 
nectariferous and non-nectariferous plants, including anemophilous plants, were counted for each honey sample. The pollen share of particular plant taxa was calculated for each sample, separately for the groups of nectariferous and non-nectariferous plants. Four quota groups were distinguished: dominant pollen $>45 \%$, secondary pollen $45-16 \%$, important minor pollen $16-3 \%$ and minor pollen $<3 \%$.

\section{RESULTS}

Among the studied samples of specific honeys, 12 were from Brassica napus, 3 from Acer, 2 from Rubus type, 2 from Salix, 1 from Robinia pseudacacia, 1 from Trifolium repens, 1 from Anthriscus type and 1 from fruit trees. The analysis of the material identified a total of 42 pollen taxa, of which 31 from nectariferous and 11 from non-nectariferous plants. The number of nectariferous taxa found in a particular sample ranged from 5 to 23 , while the number of non-nectariferous taxa ranged from 1 to 11 . The highest frequency of occurrence among nectariferous pollen was detected for Brassicaceae (others) (95.7\%), Rubus type (91.3\% and Prunus type $(86.9 \%)$. The frequency in the range of $78.3 \%$ $-70 \%$ was characteristic of pollen grains of Trifolium repens, Aesculus and Brassica napus (Tab. 2). The following shares of the dominant taxon pollen grains were found: honeys from Brassica napus 56.6\%-90.3\%, from Acer 46.1\%-77.4\%, from Salix 79.6\%-89.0\%, from Rubus type 74.1\%-76.6\%, from Robinia pseudacacia, Anthriscus type and fruit trees 48.4\%-79.3\%.
Pollen grains from anemophilous plants were found in all samples of honeys. The highest frequency in this group (69.8\%) was recorded for Poaceae (Fig. $1)$. This pollen taxon was detected in 16 samples. While analyzing the share of particular anemophilous taxa, Poaceae pollen was found to have reached a dominant status in 2 samples constituting $46.1 \%$ and $56.2 \%$ of total pollen grains of anemophilous plants found in the samples. The presence of Poaceae pollen was found to be minor in only one examined sample. A frequency within the range of $56.5 \%-52.2 \%$ was found for Quercus and Rumex pollen grains. Quercus was dominant in 6 samples reaching from $51.4 \%$ to $80 \%$, the highest fraction among all anemophilous pollen grains present in the examined honeys. The dominant pollen status was also reached by Pinus pollen grains in two samples and Chenopodiaceae pollen in one sample. The lowest frequency, less than 10\%, was found for Cerealia, Corylus avellana and Humulus lupulus (Fig. 1). Apart from a minor contribution of Poaceae pollen in one sample, a similar contribution level was noted for Rumex $(2.8 \%$ in 1 sample), Pinus (1.8\% in 1 sample) and Artemisia (1.5\% in 2 samples) (Fig. 1).

Table 3 illustrates the spectrum of pollen taxa of anemophilous plants in the examined specific honeys. The highest contribution in a sample was reached by Poaceae pollen grains in honey from fruit trees $(10 \%)$, Quercus in one honey from Brassica napus $(7.8 \%)$ and one honey from Acer (4.5\%). The pollen shares of the remaining anemophilous taxa ranged from $0.2 \%$ to $2.9 \%$ (Tab. 3). In honeys from Brassica napus, the highest

Table 1

Localities and communes of honey samples collection.

\begin{tabular}{|l|l|}
\hline \multicolumn{1}{|c|}{ Locality (sample no) } & \multicolumn{1}{c|}{ District } \\
\hline Bircza (1) & Bircza \\
\hline Boguchwała (6) & Boguchwała \\
\hline Poręby Dymarskie (1) & Cmolas \\
\hline Wilcza Wola (1) & Dzikowiec \\
\hline Grębów (1) & Grębów \\
\hline Olszany (1) & Krasiczyn \\
\hline Majdan Królewski (3) & Majdan Królewski \\
\hline Nowa Dęba (4) & Nowa Dęba \\
\hline Przemyśl (1) & Przemyśl \\
\hline Trzebuska (1) & Sokołów Małopolski \\
\hline Ustrzyki Dolne (2) & Ustrzyki Dolne \\
\hline Zbydniów (1) & Zaleszany \\
\hline
\end{tabular}


Table 2

Pollen taxa identified in examined honeys from the Rzeszów area.

\begin{tabular}{|l|c|c|}
\hline \multicolumn{1}{|c|}{$\begin{array}{c}\text { Taxa } \\
\text { (in declining frequency order) }\end{array}$} & $\begin{array}{c}\text { Frequency } \\
(\%)\end{array}$ & $\begin{array}{c}\text { Pollen participation in } \\
\text { samples (\%) }\end{array}$ \\
\hline Brassicaceae (others), Rubus type, Prunus type & $95.7-86.9$ & $0.2-76.6$ \\
\hline Trifolium repens, Aesculus, Brassica napus, Poaceae (others)* & $78.3-70.0$ & $0.2-90.3$ \\
\hline $\begin{array}{l}\text { Anthriscus type, Frangula alnus, Salix, Quercus*, Rumex*, } \\
\text { Caryophyllaceae, Malus type }\end{array}$ & $56.5-43.5$ & $0.2-89.2$ \\
\hline $\begin{array}{l}\text { Achillea type, Lotus, Phacelia, Tilia, Centaurea cyanus, Taraxacum } \\
\text { type, Trifolium pratense, Artemisia*, Cirsium type, Fagopyrum, } \\
\text { Robinia pseudacacia, Solidago type, Pinus* }\end{array}$ & $39.1-30.0$ & $0.2-79.3$ \\
\hline $\begin{array}{l}\text { Acer, Aster type, Medicago, Viola tricolor type, Betula*, Calluna, } \\
\text { Heracleum type, Impatiens, Polygonum bistorta, Cyperaceae*, } \\
\text { Crataegus, Lamium type, Melilotus, Chenopodiaceae* }\end{array}$ & $21.7-13.0$ \\
\hline $\begin{array}{l}\text { Acer platanoides, Allium type, Cynoglossum, Galeopsis, } \\
\text { Phaseolus, Sedum, Verbascum, Boraginaceae, Centaurea jacea } \\
\text { type, Cornus, Galium, Helianthus type, Malvaceae, Myosotis, } \\
\text { Polygonum persicaria type, Symphytum, Syringa, Vicia type, } \\
\text { Cerealia*, Corylus avellana*, Humulus lupulus* }\end{array}$ & $8.7-4.3$ & $0.2-77.4$ \\
\hline
\end{tabular}

* non-nectariferous anemophilous plants

Tabele 3

Share of anemophilous pollen (\%) in the microscopic image of specific honeys.

\begin{tabular}{|l|c|c|c|c|c|c|c|c|}
\hline \multirow{2}{*}{ Taxon } & \multicolumn{9}{|c|}{ Type of honey (no. of samples) } \\
\cline { 2 - 9 } & $\begin{array}{c}\text { Brassica } \\
\text { napus } \\
(12)\end{array}$ & $\begin{array}{c}\text { Acer } \\
(3)\end{array}$ & $\begin{array}{c}\text { Rubus } \\
\text { type } \\
(2)\end{array}$ & $\begin{array}{c}\text { Salix } \\
(2)\end{array}$ & $\begin{array}{c}\text { Robinia } \\
\text { pseudacacia } \\
(1)\end{array}$ & $\begin{array}{c}\text { Trifolium } \\
\text { repens } \\
(1)\end{array}$ & $\begin{array}{c}\text { From fruit } \\
\text { trees } \\
(1)\end{array}$ & $\begin{array}{c}\text { Anthriscus } \\
\text { type } \\
(1)\end{array}$ \\
\hline Poaceae (others) & $0.2-2.9$ & - & 0.5 & 0.8 & 1.6 & 1.1 & 10.0 & 0.9 \\
\hline Quercus & $0.2-7.8$ & $1.9-4.5$ & - & 2.8 & - & 0.9 & 1.1 & - \\
\hline Rumex & $0.2-1.7$ & 0.2 & 0.8 & - & 1.9 & - & - & 2.5 \\
\hline Artemisia & $0.2-0.7$ & 0.3 & - & - & 0.8 & - & - & - \\
\hline Pinus & $0.2-1.4$ & 3.2 & - & - & - & - & - & - \\
\hline Betula & $0.2-0.3$ & 1.6 & - & 0.3 & - & - & - & - \\
\hline Cyperaceae & $0.3-1.6$ & - & - & 0.3 & - & - & - & - \\
\hline Chenopodiaceae & - & - & - & 0.6 & 1.6 & - & - & - \\
\hline Cerealia & - & - & - & - & 0.3 & - & - & - \\
\hline Corylus avellana & 0.9 & 0.2 & - & - & - & - & - & - \\
\hline Humulus lupulus & 0.7 & - & - & - & - & - & - \\
\hline $\begin{array}{l}\text { No. of taxa in the } \\
\text { samples }\end{array}$ & 9 & 6 & 2 & 5 & - & - & - \\
\hline
\end{tabular}




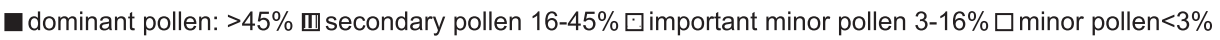

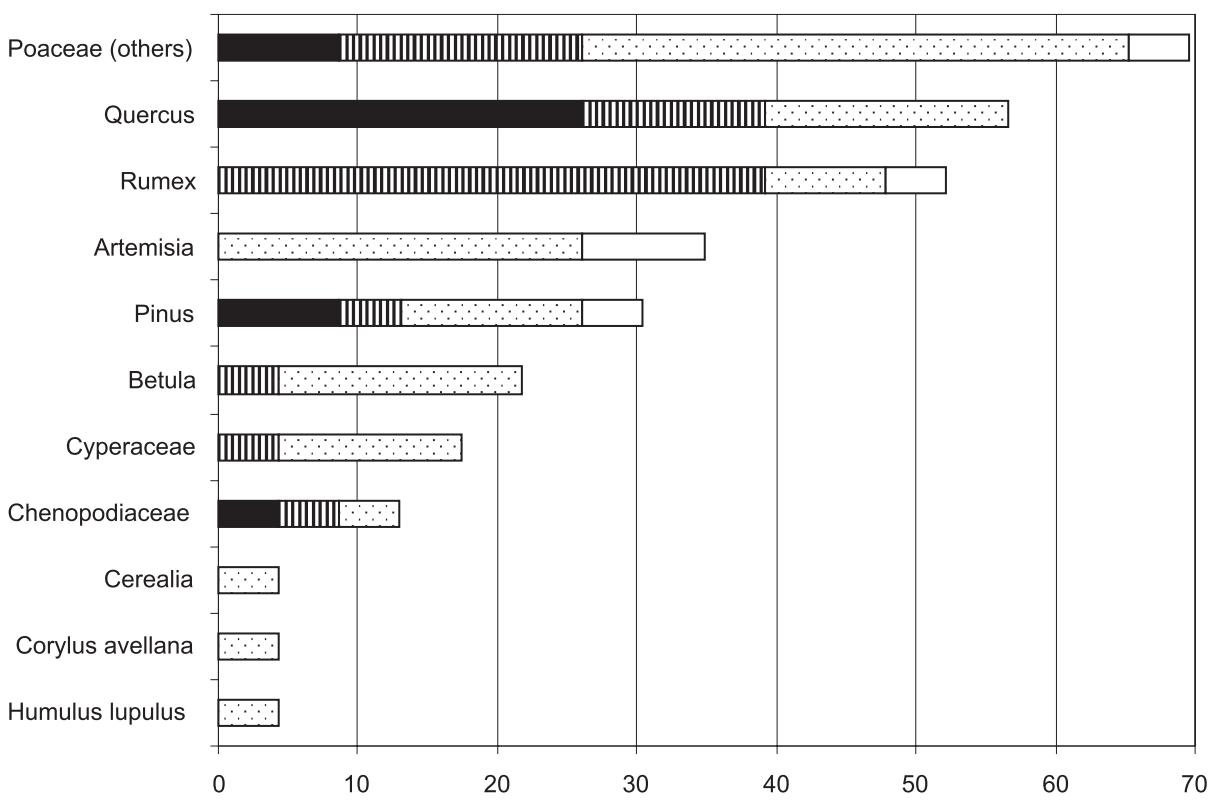

Fig. 1. Anemophilous pollen frequency and its share in non-nectariferous pollen spectrum (\%).

from Anthriscus type
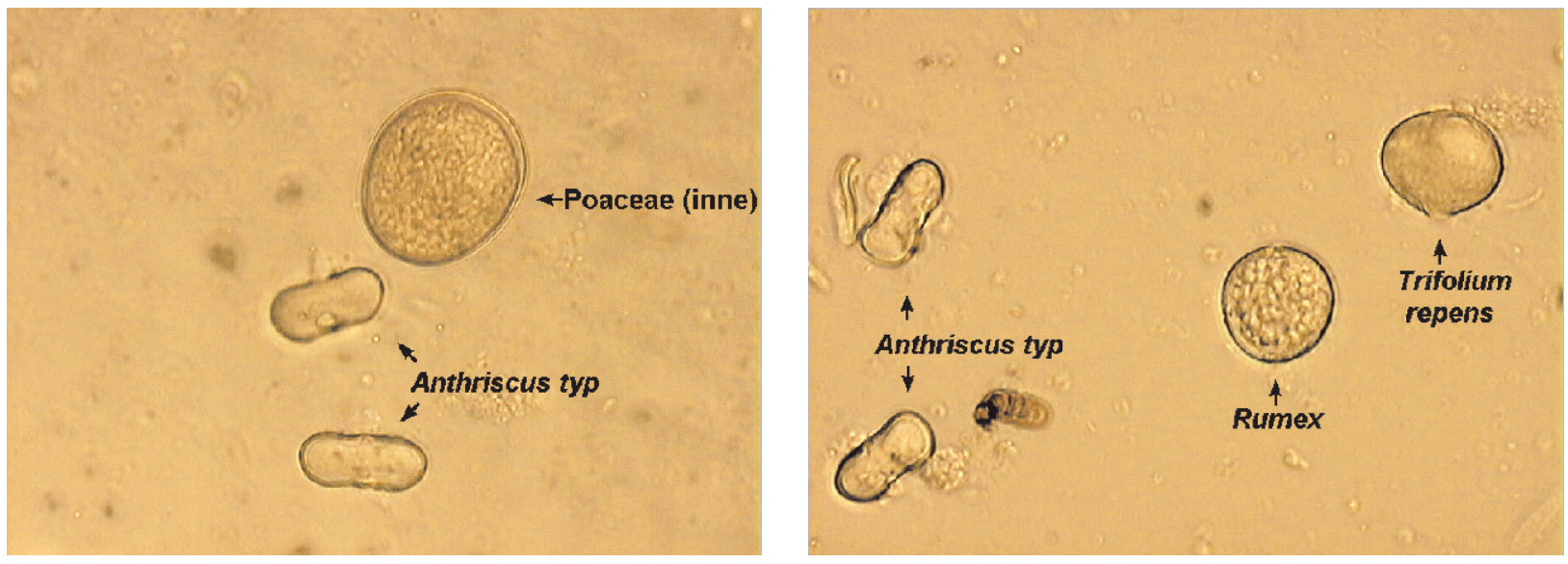

from Brassica napus
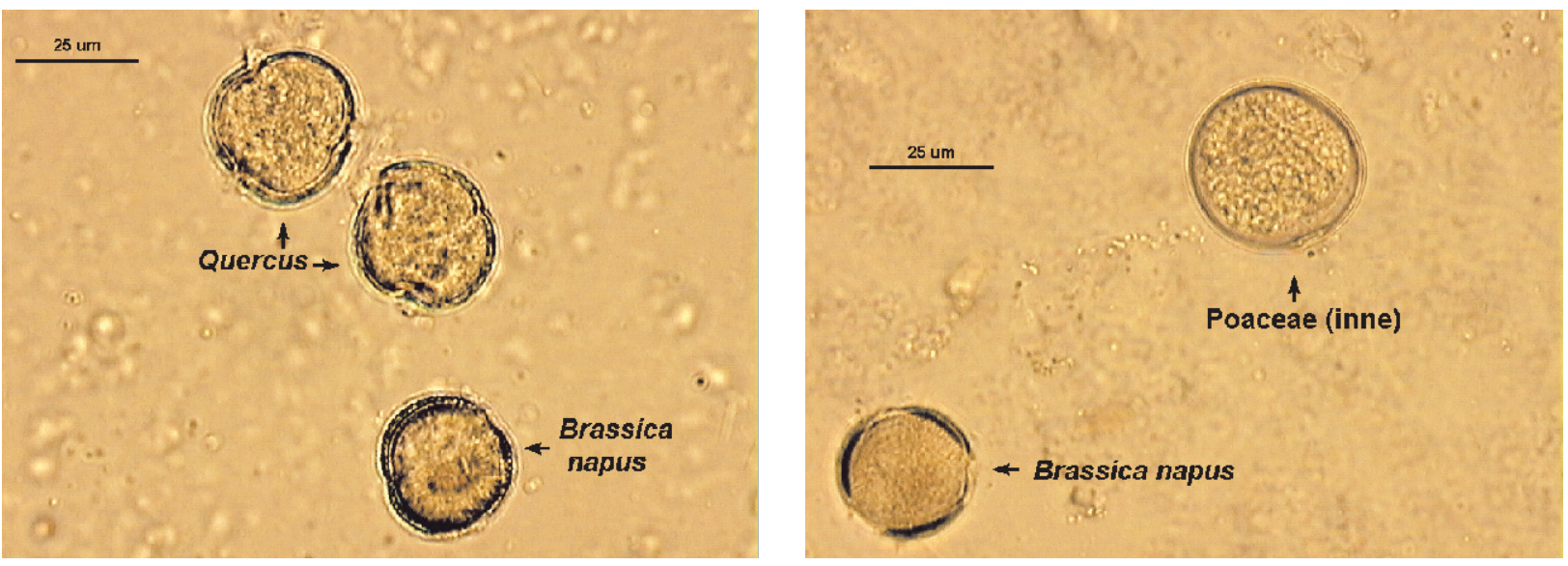

Fig. 2. Microscope image of some chosen honeys. 
frequency was shown by Poaceae pollen $(83.3 \%)$ and Quercus $(75 \%)$, while in honeys from Acer - Quercus pollen (66.7\%). The widest diversity of anemophilous pollen grains was found in honeys from Brassica napus and Acer. Fragments of microscope images of some chosen honeys are presented in Fig. 2.

Anemophilous pollen grains identified in the examined samples of honeys belong to 10 botanical families: Asteraceae, Betulaceae, Cannabaceae, Chenopodiaceae, Corylaceae, Cyperaceae, Fagaceae, Pinaceae, Poaceae, Polygonaceae. Only within the family Poaceae, 2 taxa were distinguished, namely Cerealia and Poaceae (others). On the other hand, pollen grains of nectariferous plants found in the examined honeys belong to 27 botanical families, with Asteraceae and Fabaceae being the most frequently represented.

Indicators of honeydew were found in 19 out of 23 samples of honeys. The honeydew indicator level was small in most samples ranging from 0.01 to 0.21 in honeys from Brassica napus, and in the remaining honeys between 0.01 and 1.34. Only in the honey from fruit trees, this indicator reached an average level of 2.2.

\section{DISCUSSION}

Pollen analysis revealed the presence of anemophilous pollen grains in all honey samples. One characteristic of anemophilous plants is that they produce huge quantities of pollen and that explains its presence in honeys, particularly when bees use it in case of scarcity of better flow. The nutritive value of anemophilous pollen is smaller in comparison with entomophilous plants, as noted by Maurizio (1951). Among anemophilous plants, the author included pollen of Populus, Fagus, Acer, Ulmus and Zea mays in an average value group, while pollen of Corylus avellana, Betula, Alnus, Carpinus, Pinus, Abies and Picea in a low value group. The role of anemophilous pollen for bees was also studied by S t a w i a r Z (2005).

The present study has shown that Poaceae pollen has the highest frequency in comparison with other anemophilous pollen found in the examined samples. Similar results were obtained by other authors, e.g. Warakomska (1985), when analyzing bee products from Jeleniogórska Valley, W r ó b l e w s k a (2002) in honeys from Biała Podlaska, S t a w i a r z (2006) in honeys from Świętokrzyskie Voivodship. Pollen loads with Poaceae gathered and formed by honeybees are light yellow and weigh $6.9-7.3 \mathrm{mg}$. During the high season of grass flowering, the amount of grass pollen in daily pollen loads may reach even $80 \%$ (M a urizi o and Grafl, 1969). Pollen analysis of spring specific honeys from the Rzeszów area revealed a frequency of over $50 \%$ for Quercus and Rumex pollen grains. These plants are also frequently visited by bees collecting pollen. Rumex pollen was abundantly represented in the pollen spectrum of honeys from the Podlasie Region, reaching even over $45 \%$ in one sample (Wró b le w s k a, 2002). A high frequency of Poaceae, Quercus and Rumex pollen grains in examined honeys was noted by Wróblewska and Stawiarz (2004). Additionally, pollen of Artemisia, Chenopodiaceae and Betula recorded in specific honeys of the Rzeszów area was also found present in honeys and pollen loads studied by Wa ra k o m s ka (1999). The same author found a high frequency of Artemisia and the presence of Chenopodiaceae in multifloral honeys of Lubelskie Voivodship as well as a high share of Artemisia pollen in pollen loads gathered in the Puławy town area. Pollen grains of Artemisia, whose flowering season is in summer, found in the examined spring honeys must have come from previous year's supplies of bee bread. Warakomska (1997) recorded Betula pollen in honeys from Lubelskie Voivodship and from Jeleniogórska Valley (1985). W r ó b l e w s k a (2002) recorded Betula pollen in honeys from Podlasie region. M a u ri z i o (1951) reported a very beneficial influence of Betula pollen on bee health and longevity. The flowering period for Betula lasts from the end of March till May and one stamen can release as much as ten thousand of pollen grains. Pollen loads with Betula are of yellow colour (M a u ri zi o and Grafl, 1969). The majority of anemophilous pollen grains examined in the present paper have also been observed in honeys described by other authors in this country and abroad. The results of the present study of spring specific honeys have confirmed bees' interest in anemophilous pollen, among which Poaceae, Quercus and Rumex have been found to be of particular importance. Pollen grains of Cerealia, Corylus and Humulus lupulus have been much less frequent in the examined honeys, which may be explained by the bees paying less interest in pollen of these plants. The present study, as well as the results obtained by other authors, confirms that pollen of anemophilous plants constitutes an important source of pollen flow for bees.

\section{REFERENCES}

Demianowicz A., Demianowicz Z., 1955. Nowe podstawy analizy pyłkowej miodów. / A new basis of pollen analysis of honeys. Prace Inst. Sadown., Skierniewice, 1: 185-195.

Louveaux J., Maurizio A., Vorwohl G., 1978. Methods of Melissopalynology. Bee World, 59 (4): 139-157.

Maurizio A., 1939. Untersuchungen zur quantitativen Pollenanalyse des Honiges. Mittlg. aus d. Geb der Lebensmitteluntersuchg. Hygiene, 30 (2): 1-45.

Maurizio A., 1951. Pollen analysis of honey. Bee World, 32 (1): $1-5$.

Maurizio A., Grafl I., 1969. Das Trachtpflanzenbuch. Nektar und Pollen die wichtigsten nah rungsquellen der honigbiene, Ehrenwirth., Verlag, München. 
Moar N. T., 1985. Pollen analysis of New Zealand honey. N. Z. J. Agric. Res. 28: 39-70 .

Polska Norma, Miód pszczeli. / Polish standard. Bee honey. 1988. Wyd. Normalizacyjne, PN-88,A-77626.

Ricciardelli d' Albore G., 1998. Mediterranean melissopalynology. Ed. Univ. degli studi di Perugia Fac. di Agraria, Perugia.

Sawyer R., 1981. Pollen identification for beekeepers. Ed. R. S. Pickard, Univ. College Cardiff Press, 111.

Sawyer R., 1988. Honey identification. Cardiff Acad. Press, Wales, UK, 115.

Stawiarz E., 2005. Znaczenie pyłku roślin wiatropylnych dla pszczół. / The importance of anemophilous pollen for bees. Pszczelarstwo, 4: 12-13.

Stawiarz E., 2006. Spektrum pyłkowe miodów gminy Lipnik (woj. świętokrzyskie). / The pollen spectrum of honeys from the commune of Lipnik (Świętokrzyskie Voivodship). Acta Agrobot. 59 (1): 251-256.

Warakomska Z., 1985. Obraz pyłkowy miodów i pierzgi Kotliny Jeleniogórskiej. / The pollen spectrum of honeys and propolis from Jeleniogóska Valley. Pszczeln. Zesz. Nauk. 31: 177-187.

Warakomska Z., 1997. Obraz pyłkowy wielokwiatowych miodów Lubelszczyzny. / The pollen spectrum of polyfloral honeys from the Lublin region. Mat. I Ogólnop. Konf. Nauk. Biologia kwitnienia, nektarowania i zapylania roślin, Lublin: 170-177.

Warakomska Z., Jaroszyńska T., 1992. Obraz pyłkowy miodów spadziowych Roztocza. / The pollen spectrum of honeydew honeys from the Roztocze region. Pszczeln. Zesz. Nauk. 36: 149-156.

Warakomska Z., 1999. Rośliny ogrodowe i ruderalne Puław w obrazie pyłkowym obnóży pszczelich. / Garden and ruderal plants of Puławy in the pollen spectrum of bee pollen loads. Bibl. Fragm. Agron. 6: 137-144.

Wróblewska A., 2002. Rośliny pożytkowe Podlasia w świetle analizy pyłkowej produktów pszczelich. / Flow plants of Podlasie in the light of pollen analysis of bee products. Wydawnictwo Akademii Rolniczej w Lublinie: 1-83.

Wróblewska A., Stawiarz E., 2004. Pollen spectrum of some honeys from Opatów Vicinity, Journal of Apicultural Science, 48 (2): 23-33.
Zander E., 1935, 1937. Beitrage zur Herkunftsbestimmung bei Honig. I Reichsfachgruppe Imker, Berlin, II Liedloff, Loth \& Michaelis, Leipzig: 464.

\section{Pyłek roślin wiatropylnych w wiosennych miodach odmianowych okolic Rzeszowa}

\section{Streszczenie}

Analizie pyłkowej poddano 23 próbki wiosennych miodów odmianowych okolic Rzeszowa, zebranych w latach 2005-2006 z pasiek zlokalizowanych na terenie 12 gmin. W badanym materiale wyróżniono ziarna pyłku 42 taksonów, w tym 31 z roślin nektarodajnych i 11 z nienektarodajnych wiatropylnych. Wśród roślin nektarodajnych najwyższą frekwencję osiagnęły Brassicaceae (inne) (95,7\%), Rubus typ (91,3\%) i Prunus typ $(86,9 \%)$. We wszystkich próbkach obecne były ziarna pyłku roślin wiatropylnych, wśród których najwyższą frekwencję $(69,8 \%)$ osiagnęły Poaceae. Ponad 50\% frekwencją charakteryzowały się ziarna pyłku Quercus i Rumex, zaś najniższą (poniżej 10\%) uzyskały Cerealia, Corylus avellana i Humulus lupulus. Najwyższy udział wykazały ziarna pyłku Quercus, które w jednej próbce osiągnęły aż $80 \%$ udziału wśród roślin wiatropylnych. Najniższy udział poniżej 3\% uzyskały Rumex, Pinus i Artemisia. Natomiast najwyższy udział pyłku roślin wiatropylnych wśród wszystkich taksonów w całej próbce osiagnęły Poaceae w miodzie z drzew owocowych (10\%), oraz Quercus w jednym miodzie z Brassica napus $(7,8 \%)$ i w jednym miodzie z Acer (4,5\%). Udział pyłku pozostałych taksonów wiatropylnych w badanych miodach zawierał się w granicach 0,2\%-2,9\%. Zidentyfikowane taksony roślin wiatropylnych należały do 10 rodzin botanicznych. W 19 z 23 próbek miodów obecne były nieliczne wskaźniki spadzi. 